\title{
A Facile and Efficient Synthesis of Pyrrolo[2,1-c][1,4]benzodiazepine Antitumor Antibiotics: An Improved Deprotective Cyclization Method by "Clayon"
}

\author{
B. S. Praveen Reddy, Yalamati Damayanthi and J. William Lown* \\ Department of Chemistry, University of Alberta, Edmonton, AB, Canada, T6G $2 G 2$.
}

\begin{abstract}
A facile procedure for the preparation of pyrrolo[2,1-c][1,4]benzodiazepine(PBD) imines via ethanethiol deprotective cyclization by using a mild and efficient clay supported ammonium nitrate catalyst is described. A significant improvement in yield over the customary $\mathrm{HgCl}_{2} / \mathrm{HgO}$ deprotective cyclization method is observed and the reaction proceeds with no detectable racemization.
\end{abstract}

\section{Introduction}

There is growing interest in pyrrolo[2,1-c][1,4]benzodiazepine (PBD) ring systems as synthetic targets and as potential anticancer agents. The PBDs are a class of antitumor antibiotics produced by various actinomycetes which include anthramycin, tomaymycin, neothramycin and DC-81 (1). These compounds can recognize and bind to specific sequences of double helical DNA and have potential as therapeutic agents in the treatment of certain genetic disorders including some cancers (2). They appear to exert their biological activity by reacting covalently in the minor groove of DNA to form an aminal linkage between the electrophilic carbinolamine present at the $\mathrm{C}-11$ position and the $\mathrm{N} 2$ of guanine (3). The preferred bonding sequence involves a 5'-PuGPu motif (1).

In the last few years, various strategies have been proposed for the synthesis of these antibiotics and have met with varying degrees of success while exhibiting different limitations (4) It has been found that the key introduction of the imine at N10-C11 position has consistently presented problems due to the reactivity of this functional group. One of the most generally: employed methods is the deprotective cyclization of amino thioacetals by employing mercuric chloride in aqueous acetonitrile. However, in the application of this method the isolation of the product is problematic and results in low yields due to adsorption following formation of excess 
amounts of mercuric salts and concomitant hydration to form the corresponding carbinolamine (4, 5).

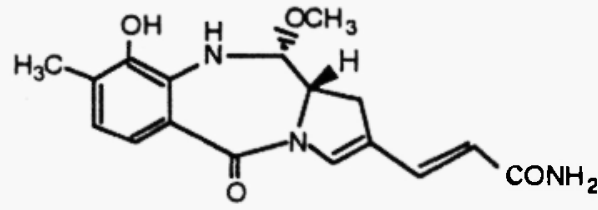

Anthramycin

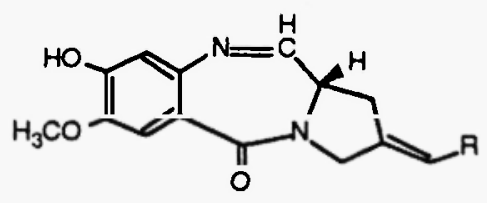

Tomaymycin

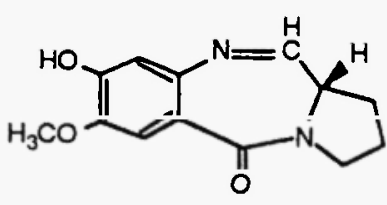

DC-81

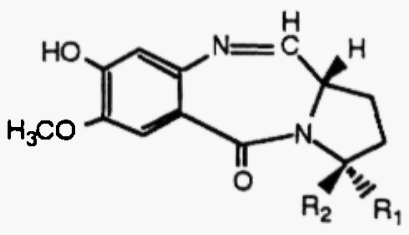

Neothramycin $A\left(R_{1}=H ; R_{2}=O H\right)$

Neothramycin $B\left(R_{1}=O H ; R_{2}=H\right)$

\section{Results and Discussion}

Our interest in the design and the synthesis of novel PBD-lexitropsin conjugates has led us to search for novel mild and selective deprotective cyclization methods for the synthesis of PBD imines. A recent report of a mild and efficient dethioacetalization by using clay supported ammonium nitrate, a non-metallic catalyst (6), prompted us to explore its application in the synthesis of the PBD ring system. This proved to be a simple and efficient method to obtain PBD imines by dethioacetalization of aminothioacetals and in very good yields. This "clayon" method thus solved an additional major problem, which accompanies the $\mathrm{HgCl}_{2} / \mathrm{HgO}$ method, which is the formation of a mixture of imine and carbinolamine due to the necessary use of high proportion of water $(25 \%)$ combined with acetonitrile as the solvent. In contrast, in the present case, since the reaction is carried out in dichloromethane alone, the possibility of the formation of carbinolamine can be completely avoided. Thus the convenience, selectivity, high degree of stereochemical retention and high yields represent significant improvements of this procedure over the existing methods.

The starting materials $\underline{4}$ were synthesized according to the route presented in the Scheme by coupling the appropriate 2 -nitrobenzoic acids $\underline{1}$ via their acid chlorides with (S)-proline methyl ester hydrochlorides $\underline{\mathbf{2}}$ to afford the $(2 S)$ - N-(2-nitrobenzoyl)pyrrolidine-2-carboxylate esters $\underline{\mathbf{3}}$. This latter compound upon reduction with DIBAL-H (2eq.) afforded the corresponding aldehyde and was followed by protection to afford the (2S)- $\mathrm{N}$-(2-nitrobenzoyl)pyrrolidine-2-carboxaldehyde diethyl thioacetals $\underline{4}(4 \mathrm{~b})$. These latter nitrothioacetals $\underline{4}$ were reduced by $10 \% \mathrm{Pd} / \mathrm{C}$ to the corresponding (2S)-N-(2-amino benzoyl) pyrrolidine-2-carboxaldehyde diethyl thioacetals. 
Finally the deprotective cyclization with clay supported ammonium nitrate "clayon" afforded PBD imine $\underline{\mathbf{5}}$ in $70-75 \%$ isolated yields (7).<smiles>[R]C1=[I-]([2H])C=C(C(=O)O)C([N+](=O)[O-])=C1</smiles>

$1(\mathbf{a - c})$ i) $\mathrm{SOCl}_{2} / \mathrm{C}_{6} \mathrm{H}_{6} / \mathrm{r} \cdot \mathrm{t} / 2-3 \mathrm{~h}$. ii)L-Proline methyl ester hydrochlonde $(2) / \mathrm{Et}_{3} \mathrm{~N} / \mathrm{CH}_{2} \mathrm{Cl}_{2} / 0^{\circ} \mathrm{C}$<smiles>[R2]c1cc2c(cc1[R2])C(=O)N1CCC[C@H]1C=N2</smiles>

5(a-c) v) $\mathrm{H}_{2} / \mathrm{Pd}-\mathrm{C} / \mathrm{MeOH} / 2 \mathrm{~h}$.

vi) Clayon $/ \mathrm{CH}_{2} \mathrm{Cl}_{2} / \mathrm{r} . / 2428 \mathrm{~h}$ iii) DIBAL-H/CH ${ }_{2} \mathrm{O}_{2} /-78^{\circ} \mathrm{C} / 1 \mathrm{~h}$ iv) $\mathrm{EtSH} /\left(\mathrm{CH}_{3}\right)_{3} \mathrm{SiCl} / \mathrm{CH}_{2} \mathrm{Cl}_{2} / \mathrm{r} \cdot \mathrm{t}_{2} \mathrm{O}-2$ th<smiles>[R6]c1cc(C(=O)N2CCC[C@H]2C(C)=O)c([N+](=O)[O-])cc1[R2]</smiles>

3(a-c)

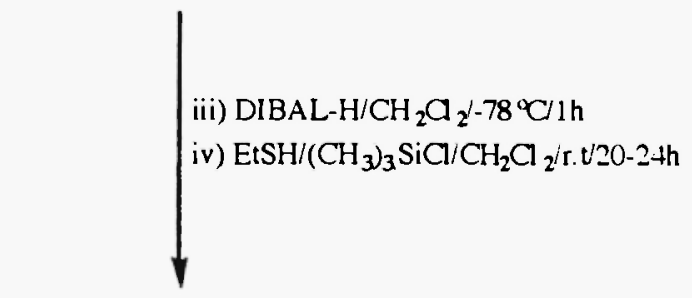

$4(a-c)$

a) $\mathrm{R}_{1}=\mathrm{R}_{2}=\mathrm{H}$; b) $\mathrm{R}_{1}=\mathrm{OCH}_{2} \mathrm{Ph}, \mathrm{R}_{2}=\mathrm{OCH}_{3}$; c) $\mathrm{R}_{1}=\mathrm{OH}, \mathrm{R}_{2}=\mathrm{OCH}_{3}$

\section{Scheme}

In summary, this simple new deprotective cyclization procedure overcomes the difficulties involved in the $\mathrm{HgCl}_{2} / \mathrm{HgO}$ method and significantly improves the efficiency of the methodology. It is a mild and simple method applicable to the synthesis of DNA interactive PBD imines in very good yields and should assist researchers in the field attempting to develop improved anticancer agents.

Acknowledgement: This research was supported by a grant (to JWL) from the National Cancer Institute of Canada. 


\section{References and Notes:}

1. D. E. Thurston, Advances in the Study of Pyrrolo[2,1-c][1,4]benzodiazepine (PBD) Antitumor Antibiotics. In the Molecular Aspects of Anticancer Drug - DNA Interactions; S. Neidle, M. I. Waring: Eds. The Macmillan Press Ltd.: London, 1993, pp54-88.

2. D. E. Thurston and A. S. Thompson, Chem.Brit. 767 (1990).

3. L. H. Hurley and R. L. Petrusek, Nature (London! 282, 529 (1979).

4. (a) W. Leimgruber, A. D. Batcho and R. C. Czajkowski, J. Am. Chem. Soc. 90, 5641 (1968) (b) D. E. Thurston and D. R. Langley, J. Org. Chem. 52, 91 (1989). (c) A. Kamal, B. S. P. Reddy and B. S. N. Reddy, Tetrahedron Lett., $37_{2} 6803$ (1996). (d) A. Kamal, B. S. P. Reddy and B. S. N. Reddy, Bioorg. Med. Chem. Lett., I 1825 (1997). (e) A. Kamal, Y.Damayanthi, B. S. N. Reddy, B. Lakminarayana, and B. S. P. Reddy, Chem. Commun. 1015 (1997). (f) A. Kamal, P. W. Howard, B. S. N. Reddy, B. S. P. Reddy and D. E. Thurston, Tetrahedron, 53, 3223 (1997). (g) A. Kamal and N. V. Rao, Chem. Commun., 385 (1996).

5. D. E. Thurston and D. S. Bose, Chem. Rev. 94,433 (1994).

6. H. M. Meshram, G. S. Reddy and J. S. Yadav, Tetrahedron Lett. $\underline{38}_{2} 8891$ (1997).

7. The general procedure for deprotective cyclization is as follows: To a solution of the amino thioacetals (4) $(0.1 \mathrm{~g}, 0.3 \mathrm{mmol})$ in dichloromethane $(20 \mathrm{~mL})$ was added powdered clay supported ammonium nitrate clayon $6(1 \mathrm{~g}, \mathrm{w} / \mathrm{w})$. The mixture was stirred at r.t. in a nitrogen atmosphere for 24-28 h. Upon complete conversion of the starting material, as indicated by tlc, the catalyst was removed by filtration through celite. The filtrate was evaporated and the residue was purified by flash chromatography on a silica (230-400 mesh) column using ethyl acetate as an eluent to afford PBD imine in 70-75\% yield. 5a ${ }^{1} \mathrm{HNMR}\left(\mathrm{CDCl}_{3}\right): \delta 1.62-$ $2.40(\mathrm{~m}, 4 \mathrm{H}), 3.32-4.01(\mathrm{~m}, 3 \mathrm{H}), 7.01-7.52(\mathrm{~m}, 3 \mathrm{H}), 7.60(\mathrm{~d}, 1 \mathrm{H} \mathrm{J}=3.2 \mathrm{~Hz}), 7.98(\mathrm{~d}, 1 \mathrm{H}$ $\mathrm{J}=5.1 \mathrm{~Hz}) ;$ IR $\left(\mathrm{CHCl}_{3}\right): 3250-3300,2965,1625,1545,1480,1230,860 \mathrm{~cm}^{-1} ; \mathrm{MS}: \mathrm{m} / \mathrm{z}$ $200\left(\mathrm{M}^{+} .100 \%\right) ;[\alpha]_{\mathrm{D}}^{22}=+450\left(\mathrm{c}, 0.61, \mathrm{CHCl}_{3}\right)\left[\mathrm{lit}^{8}[\alpha]^{22}=+318\left(\mathrm{c}, 0.147, \mathrm{CHCl}_{3}\right)\right.$; lit. $\left.{ }^{9}[\alpha]^{25}=+309\left(\mathrm{c}, 0.25, \mathrm{CHCl}_{3}\right)\right]$.

8. J. W. Lown and A. V. Joshua, Biochemical Pharmacology, 28 2017 (1979).

9. A. Kamal, B. S. P. Reddy and B. S. N. Reddy, Tetrahedron Lett. 37, 2281 (1996).

Received on August 6, 1998 